\title{
A STUDY OF GLYCOLYSIS
}

\author{
BY ADELAIDE P. BARER
}

(From the Laboratory of Pathological Chemistry, University Hospitals, State University of Iowa, Iowa City)

(Received for publication February 25, 1931)

\section{INTRODUCTION}

Since Claude Bernard (1) first noted the disappearance of sugar from drawn blood in 1856 this phenomenon has been the subject of much interest and investigation. Following the discovery of insulin, studies on glycolysis were made with renewed interest in the hope that experiments in vitro might shed some light upon the rôle of insulin in carbohydrate metabolism. The rate of disappearance of sugar from blood in vitro and the rate of glycolysis are commonly considered to be synonymous, a custom which will be followed in this discussion. The accumulated data on glycolysis show a very striking lack of uniformity. The purpose of this report is to present a series of observations on glycolysis and to discuss some of the principal factors influencing the rate and the amount of sugar glycolyzed.

\section{METHOD}

Patients in the University Hospital served as subjects for the following experiments. They were unselected except that no patient with an abnormally high nonprotein nitrogen content of the blood was used. From each patient $10 \mathrm{cc}$. of blood was drawn two or two and one-half hours after a meal. This blood, with the exception of one-half cc. for the determination of the initial sugar content, was transferred immediately to a sterile $50 \mathrm{cc}$. Erlenmeyer flask containing a bent paper clip. The flask was loosely stoppered with sterile cotton, shaken for fifteen minutes to defibrinate the blood and incubated in a moist chamber at $37^{\circ} \mathrm{C}$. The blood was well shaken before and after each of the sugar determinations, which were made at two hour intervals according to the method of Gibson, Mitchell and Larimer (2). 
TABLE I

Total sugar glycolyzed in a series of bloods

\begin{tabular}{|c|c|c|c|c|c|c|c|c|}
\hline \multirow{2}{*}{ Case } & \multirow{2}{*}{ Diagnosis } & \multirow{2}{*}{ Sex } & \multirow{2}{*}{ Age } & \multicolumn{5}{|c|}{ Total sugar glycolyzed: Hours } \\
\hline & & & & 2 & 4 & 6 & 8 & 10 \\
\hline & & & 气ั้ & $\begin{array}{c}m g m . \\
\text { per } \\
100 c c\end{array}$ & $\begin{array}{c}m g m . \\
\text { per } \\
100 c c\end{array}$ & $\begin{array}{c}\text { mgm. } \\
\text { per } \\
100 \mathrm{cc}\end{array}$ & $\begin{array}{l}m g m . \\
\text { per }\end{array}$ & $\begin{array}{c}m g m . \\
\text { per } \\
\text { per }\end{array}$ \\
\hline 1. & Myelogenous leukemia. . & M & 59 & 98 & $128^{*}$ & & & \\
\hline 2. & Myelogenous leukemia. . & M & 48 & 94 & $158^{*}$ & & & \\
\hline 3. & Diabetes mellitus..... & M & 50 & 93 & 103 & 166 & 179 & $223^{*}$ \\
\hline 4. & Myelogenous leukemia. . & $\mathrm{F}$ & 59 & 87 & $118^{*}$ & & & \\
\hline 5. & Myelogenous leukemia... & $\mathrm{F}$ & 41 & 81 & 148 & $186^{*}$ & & \\
\hline 6. & Congenital heart disease. & $\mathrm{M}$ & 30 & 80 & $112^{*}$ & & & \\
\hline 7. & Diabetes mellitus $\ldots \ldots \ldots \ldots$ & $\mathrm{M}$ & 49 & 75 & 143 & 215 & & 242 \\
\hline \multirow[t]{2}{*}{8.} & $\begin{array}{l}\text { Chronic endocarditis, cardiac } \\
\text { decompensation, osteoar- }\end{array}$ & & & & & & & \\
\hline & thritis . . . . . . . . & M & 57 & 71 & 108 & $132^{*}$ & & \\
\hline 9. & Multiple fractures, empyema & M & 56 & 69 & 129 & $149^{*}$ & & \\
\hline 10. & Gastric neurosis $\ldots \ldots \ldots \ldots$ & M & 51 & 68 & 100 & $128^{*}$ & & \\
\hline \multirow{2}{*}{11.} & Malignant lymphomata, & & & & & & & \\
\hline & Hodgkins type. . . . . . . & $\mathrm{F}$ & 20 & 67 & $128^{*}$ & & & \\
\hline \multirow[t]{2}{*}{12.} & Arteriosclerosis, hypertrophy & & & & & & & \\
\hline & of prostate $\ldots \ldots \ldots \ldots$ & M & 57 & 63 & 119 & $162^{*}$ & & \\
\hline \multirow[t]{2}{*}{13.} & Banti's disease, parotitis epi- & & & & & & & \\
\hline & $\operatorname{demic} \ldots \ldots \ldots \ldots \ldots$ & $\mathrm{F}$ & 22 & 63 & $110^{*}$ & & & \\
\hline 14. & Septicopyemia . . . . & $\mathrm{F}$ & 27 & 57 & 97 & $136^{*}$ & & \\
\hline 15. & Arsenical hepatitis . . . . . . . . & M & 30 & 53 & 93 & 133 & & \\
\hline 16. & Hysteria $\ldots \ldots \ldots \ldots \ldots$ & $\mathrm{F}$ & 26 & 53 & 76 & $103^{*}$ & & \\
\hline \multirow[t]{2}{*}{17.} & Chronic myocarditis, hyper- & & & & & & & \\
\hline & tension $\ldots \ldots \ldots \ldots \ldots$ & M & 47 & 50 & 90 & 143 & & \\
\hline \multirow[t]{2}{*}{18.} & Mixed tumor of parotid gland & & & & & & & \\
\hline & with generalized metastases. & M & 18 & 50 & 99 & 133 & & \\
\hline 19. & Psychoneurosis. . . . . . . . . . & M & 39 & 50 & 100 & 140 & $175^{*}$ & \\
\hline \multirow[t]{2}{*}{20.} & Pulmonary tuberculosis, tu- & & & & & & & \\
\hline & bercular peritonitis. . . . . . & M & 31 & 50 & 103 & & & \\
\hline 21. & Mitral stenosis. . . . . . . . & M & 43 & 49 & 87 & $117^{*}$ & & \\
\hline 22. & Arsenical hepatitis. . & M & 23 & 48 & 95 & $130^{*}$ & & \\
\hline 23. & Peptic ulcer. . . . . . . & $\mathrm{F}$ & 30 & 48 & 83 & $127^{*}$ & & \\
\hline 24. & Diabetes mellitus... & M & 27 & 47 & 86 & $127^{*}$ & & \\
\hline 25. & Pernicious anemia $\ldots \ldots \ldots$ & $\mathrm{F}$ & 45 & 47 & 77 & $110^{*}$ & & \\
\hline \multirow[t]{2}{*}{26.} & Chronic progressive vascular & & & & & & & \\
\hline & nephritis, chronic uremia. . & M & 60 , & 46 & 91 & & & \\
\hline 27. & Exophthalmic goiter. . . . . & $\mathbf{F}$ & 41 & 44 & 82 & $121^{*}$ & & \\
\hline \multirow[t]{2}{*}{28.} & Diabetes mellitus, adenoma of & & & & 96 & & & \\
\hline & & M & 34 & 44 & 90 & & & \\
\hline
\end{tabular}


TABLE I-Continued

\begin{tabular}{|c|c|c|c|c|c|c|c|c|}
\hline \multirow{2}{*}{ Case } & \multirow{2}{*}{ Diagnosis } & \multirow{2}{*}{ Sex } & \multirow{2}{*}{ Age } & \multicolumn{5}{|c|}{ Total sugar glycolyzed: Hours } \\
\hline & & & & 2 & 4 & 6 & 8 & 10 \\
\hline 29. & Syphilitic aortitis aortic in- & & ֶั้ & $\begin{array}{l}\text { mgm. } \\
\text { per } \\
100 c c .\end{array}$ & $\begin{array}{l}\text { mgm. } \\
\text { per } \\
100 \text { cc. }\end{array}$ & $\begin{array}{l}\text { mgm. } \\
\text { per } \\
100 \text { cc. }\end{array}$ & $\begin{array}{l}\underset{\text { mgm. }}{\text { per }} \\
100 \mathrm{cc} .\end{array}$ & $\begin{array}{l}\text { mgm. } \\
\text { per } \\
100 \text { cc. }\end{array}$ \\
\hline & sufficiency............. & $\mathbf{M}$ & 62 & 44 & 98 & $140^{*}$ & & \\
\hline 30. & $\begin{array}{l}\text { Chronic myocarditis, chronic } \\
\text { rheumatic endocarditis, la- }\end{array}$ & & & & & & & \\
\hline & & $F$ & 34 & 43 & 72 & $96^{*}$ & & \\
\hline 31. & Chronic cholecystitis . . . . . . & $\mathbf{M}$ & 30 & 43 & 87 & $120^{*}$ & & \\
\hline 32. & Bronchopneumonia . . . . . . . & $\mathbf{M}$ & 53 & 42 & 82 & $120^{*}$ & & \\
\hline 33. & $\begin{array}{l}\text { Arteriosclerosis, gangrene of } \\
\text { toe } \ldots \ldots \ldots \ldots \ldots \ldots \ldots \ldots\end{array}$ & $\mathrm{M}$ & 50 & 42 & 83 & & $149^{*}$ & \\
\hline 34. & Cardiac decompensation. .... & $M$ & 61 & 42 & 102 & $132^{*}$ & & \\
\hline 35. & $\begin{array}{l}\text { Malignant lymphomata } \\
\text { Hodgkins type.......... }\end{array}$ & $\mathrm{M}$ & 43 & 41 & 69 & & & \\
\hline 36. & Pernicious anemia . . . . . . & $\mathrm{F}$ & 59 & 40 & 74 & 93 & $149^{*}$ & \\
\hline 37. & Diabetes mellitus. . . . . . . . & $\mathrm{M}$ & 15 & 36 & 128 & 172 & 232 & \\
\hline 38. & $\begin{array}{l}\text { Chronic rheumatic endocardi- } \\
\text { tis. } \ldots \ldots \ldots \ldots \ldots \ldots \ldots \ldots\end{array}$ & $\mathrm{Mi}$ & 58 & 36 & & & & \\
\hline 39. & Chronic interstitial nephritis. & $\mathbf{M}$ & 42 & 35 & 77 & 146 & 164 & $203^{*}$ \\
\hline 40. & Tuberculosis . . . . . . . . . . & $\mathbf{M}$ & 53 & 35 & 63 & $105^{*}$ & & \\
\hline 41. & Arteriosclerosis. . . . . . . . . & $\mathbf{M}$ & 71 & 34 & 71 & 97 & $145^{*}$ & \\
\hline 42. & Visceroptosis. . . . . . . & M & 24 & 34 & 94 & 114 & & \\
\hline 43. & Pernicious anemia.... & $\mathbf{M}$ & 68 & 34 & $82^{*}$ & & & \\
\hline 44. & Lymphocytic leukemia . . . . . . & $\mathbf{M}$ & 20 & 34 & 57 & 95* & & \\
\hline 45. & Cardiospasm. . . . . . . . . & $\mathbf{M}$ & 59 & 33 & 78 & & & \\
\hline 46. & $\begin{array}{l}\text { Hypertension, cardiac decom- } \\
\text { pensation } . \cdots \ldots \ldots \ldots \ldots\end{array}$ & $\mathbf{M}$ & 64 & 33 & 58 & $90^{*}$ & & \\
\hline 47. & Catarrhal jaundice.......... & $\mathbf{M}$ & 39 & 33 & 80 & $114^{*}$ & & \\
\hline 48. & Subacute nephritis ........ & $\mathbf{M}$ & 34 & 32 & 66 & 119 & $175^{*}$ & \\
\hline 49. & Cardiac decompensation..... & $\mathrm{M}$ & 43 & 32 & 89 & 148 & $172^{*}$ & \\
\hline 50. & $\begin{array}{c}\text { Diabetes mellitus, gangrene of } \\
\text { toe..................... }\end{array}$ & $M i$ & 57 & 31 & 72 & 107 & 175 & 252 \\
\hline 51. & $\begin{array}{l}\text { Multiple leiomyomata of } \\
\text { uterus } \ldots \ldots \ldots \ldots \ldots \ldots \ldots\end{array}$ & $\mathrm{F}$ & 28 & 31 & 78 & $115^{*}$ & & \\
\hline 52. & Chronic hypertrophic arthri- & & & & & & & \\
\hline & & $\mathbf{M}$ & 42 & 30 & 64 & $93^{*}$ & & \\
\hline 53. & Psychoneurosis........... & $\mathbf{F}$ & 37 & 29 & 83 & $132^{*}$ & & \\
\hline 54. & Pleurisy with effusion...$\ldots$ & $\mathbf{M}$ & 24 & 28 & 54 & & & \\
\hline 55. & Arteriosclerosis. . . . . . . . . & $\mathbf{M}$ & 68 & 28 & 60 & $108^{*}$ & & \\
\hline 56. & $\begin{array}{c}\text { Angina pectoris, cardiac de- } \\
\text { compensation. } \ldots \ldots \ldots \ldots \ldots\end{array}$ & $M:$ & 71 & 27 & 66 & 111 & & $172^{*}$ \\
\hline
\end{tabular}


TABLE I-Continued

\begin{tabular}{|c|c|c|c|c|c|c|c|c|}
\hline \multirow{2}{*}{ Case } & \multirow{2}{*}{ Diagnosis } & \multirow{2}{*}{ Sex } & \multirow{2}{*}{ Age } & \multicolumn{5}{|c|}{ Total sugar glycolyzed: Hours } \\
\hline & & & & 2 & 4 & 6 & 8 & 10 \\
\hline & & & है & $\begin{array}{c}\text { mgm. } \\
\text { per } \\
100 \text { cc. }\end{array}$ & $\begin{array}{c}\operatorname{mgm} . \\
\text { per } \\
100 \mathrm{cc} .\end{array}$ & $\begin{array}{c}\text { mgm. } \\
\text { per } \\
100 \text { cc. }\end{array}$ & $\begin{array}{c}\operatorname{mgm} . \\
\text { per } \\
100 \text { cc. }\end{array}$ & $\begin{array}{c}m g m . \\
\text { per. } \\
100 \\
\text { cc. }\end{array}$ \\
\hline 57. & Arsenical hepatitis. & $\mathbf{M}$ & 39 & 26 & .60 & & & \\
\hline 58. & Carcinoma of stomach. & $\mathbf{M}$ & 61 & 26 & 76 & & & \\
\hline 59. & Senile cataract . . . . . . . & $\mathbf{F}$ & 63 & 25 & 46 & 80 & & \\
\hline 60. & Diabetes mellitus $\ldots \ldots \ldots \ldots$ & $\mathrm{F}$ & 60 & 24 & 70 & 94 & 118 & 165 \\
\hline \multirow[t]{2}{*}{61.} & Chronic myocarditis, hyper- & & & & & & & \\
\hline & tension $\ldots \ldots \ldots \ldots \ldots \ldots$ & $\mathbf{M}$ & 47 & 24 & 76 & & & \\
\hline 62. & Senile cataract ........ & $\mathrm{F}$ & 74 & 24 & 57 & 68 & $102^{*}$ & \\
\hline 63. & Choroiditis............ & $\mathrm{F}$ & 65 & 24 & 65 & 84 & $126^{*}$ & \\
\hline 64. & Lymphocytic leukemia...... & $\mathrm{F}$ & 24 & 23 & 64 & & & \\
\hline 65. & $\begin{array}{l}\text { Pulmonary tuberculosis, tu- } \\
\text { bercular peritonitis. }\end{array}$ & & & & & & & \\
\hline 66. & Lymphocytic leukemia...... & $\begin{array}{l}\mathbf{M} \\
\mathbf{M}\end{array} \mid$ & $\begin{array}{l}31 \\
20\end{array}$ & 23 & $\begin{array}{l}34 \\
64\end{array}$ & $126^{*}$ & & \\
\hline 67. & Polycythemia vera......... & $\mathbf{M}$ & 44 & 22 & 62 & & & \\
\hline 68. & Syphilis. . . . . . . . . . & $\mathbf{M}$ & 63 & 22 & 44 & $65^{*}$ & & \\
\hline 69. & Myelogenous leukemia. & $\mathrm{F}$ & 66 & 22 & 79 & & & \\
\hline 70. & Senile cataract . . . . . . & $\mathbf{M}$ & 70 & 21 & 71 & 95 & $129^{*}$ & \\
\hline 71. & Pernicious a nemia . & $\mathrm{F}$ & 27 & 21 & 42 & & & \\
\hline 72. & Pernicious anemia. & $\mathbf{M}$ & 68 & 21 & 71 & & & \\
\hline 73. & Gangrene toe $\ldots \ldots \ldots \ldots$ & $\mathbf{M}$ & 50 & 20 & 64 & & $117^{*}$ & \\
\hline \multirow[t]{2}{*}{74.} & Gangrenous appendix, pelvic & & & & & & & \\
\hline & abscess. . . . . . . . . . & $\mathbf{M}$ & 47 & 20 & 85 & $126^{*}$ & & \\
\hline 75. & Latent syphilis, peptic ulcer. & $\mathbf{M}$ & 32 & 18 & 63 & & & \\
\hline 76. & Diabetes mellitus ........ & $\mathbf{M}$ & 34 & 18 & 60 & 113 & 138 & 170 \\
\hline 77. & Adenoma of thyroid. & $\mathrm{F}$ & 32 & 18 & 85 & & $138^{*}$ & \\
\hline 78. & Chronic appendicitis. . & $\mathrm{F}$ & 25 & 16 & 43 & 75 & 107 & $138^{*}$ \\
\hline 79. & Cardiac decompensation..... & $\mathbf{M}$ & 43 & 15 & 47 & 101 & $140^{*}$ & \\
\hline \multirow[t]{2}{*}{80.} & $\begin{array}{l}\text { Diabetes mellitus, cardiac de- } \\
\text { compensation, chronic myo- }\end{array}$ & & & & & & & \\
\hline & carditis $\ldots \ldots \ldots \ldots \ldots$ & $\mathbf{M}$ & 43 & 11 & 61 & 98 & $128^{*}$ & \\
\hline
\end{tabular}

* Initial blood sugar: the blood was completely glycolyzed when analyzed at the end of this period.

Stained smears were made from each specimen of the blood at the end of each experiment, and in no case were microorganisms found. Complete blood counts were obtained on the day of the study.

\section{RESULTS AND DISCUSSION}

The rates of glycolysis in $\mathbf{8 0}$ specimens of blood from patients with widely different diseases are recorded in Table $I$. It will be observed 
that the amount of sugar glycolyzed during a two hour period of observation varied from $11 \mathrm{mgm}$. to $98 \mathrm{mgm}$. per $100 \mathrm{cc}$. of blood. The variation in the glycolytic activity of different bloods is more evident in this table than in previously reported data. There are instances, notably those reported by Falcon-Lesses (3) and by Schmitz and Glover (4), in which a large amount of sugar was glycolyzed. Likewise there are observations in which the rate of glycolysis was very low (Birchard (5), White and Watson (6), John (7), and Lemann and Liles (8)). There is in this study no correlation of the age or sex of the patient and the rate of glycolysis.

An examination of the methods used will do much to explain the variation in results obtained by different investigators. The most important cause for the diversified results in glycolytic studies has been the use of anticoagulants. Bürger (9) has demonstrated that the addition of citrate or oxalate affects the rate of glycolysis. Data obtained in this laboratory showed further that the glycolytic power of blood is retarded in proportion to the concentration of citrate or oxalate. Fluoride arrests glycolysis, as has been demonstrated by Major (10), and by Dickens and Simer (11). Hence all data obtained with blood to which oxalate, citrate or fluoride has been added cannot be compared with results obtained without the use of these anticoagulants. Defibrination or heparinization of blood does not affect the rate of glycolysis (3) (4) (12).

Of other extrinsic factors which might influence the rate of glycolysis, temperature is of great importance. Claude Bernard (1) employed a temperature of $15^{\circ} \mathrm{C}$., Lemann and Liles (8) kept their specimens of blood between $9^{\circ}$ and $11^{\circ} \mathrm{C}$., Denis and Giles (13), Mauriac (14), and Stammers (15) all used "room temperature." Thalhimer and Perry (16), Cajori and Crouter (17), Katayama (18), Negelein (19) and Mackenzie (20) used a temperature of $37-38^{\circ} \mathrm{C}$. Bürger (9) demonstrated that the optimum temperature for glycolysis was $37^{\circ} \mathrm{C}$., an observation which has been confirmed in this laboratory. It is to be regretted that the data on the rate of glycolysis given by different investigators often cannot be compared because standard temperature conditions were not maintained.

The influence of the initial sugar concentration on the rate of glycolysis has been the subject of much discussion. Some investigators 
(5) (7) (8) (21) have taken as the rate of glycolysis the percentage of the initial sugar content which is glycolyzed in two hours. This is arbitrary and illogical since the absolute rate of glycolysis does not appear to be dependent upon the initial sugar concentration. In the author's blood specimens the initial sugar content varied from 65 mgm. per $100 \mathrm{cc}$. (Case 68) to $1084 \mathrm{mgm}$. per $100 \mathrm{cc}$. (Case 37), but the absolute rate of glycolysis in the blood of the latter patient with its excessive amount of sugar was well within the limits of normal for this series. Further, it was observed (Table II) that the rate of glycolysis

TABLE II

Glycolysis of excessively high blood sugar (Case H. M.)

$\begin{array}{lcc}\text { Hours } & \begin{array}{c}\text { Blood sugar } \\ m \text { mm. per } 100 c c\end{array} & \begin{array}{c}\text { Sugar glycolyzed } \\ m g m . \text { per } 100 c c .\end{array} \\ 0 & \delta 0 u & 0 \\ 2.0 & 725 & 75 \\ 4.0 & 655 & 145 \\ 6.0 & 585 & 215 \\ 10.0 & 558 & 242 \\ 18.5 & 455 & 345 \\ 23.0 & 312 & 488 \\ 41.5 & 120 & 680 \\ 65.5 & 45 & 755 \\ 72.0 & 0 & 800\end{array}$

continues to be about the same for six hours, even though the concentration of sugar is decreasing steadily. The decrease in the rate of glycolysis which occurs after six hours is probably due to mechanical and chemical damage to the blood cells. Cajori and Crouter (17) and Macleod (22) have demonstrated that exogenous glucose is glycolyzed at the same rate as endogenous blood sugar. This fact has been confirmed repeatedly in this laboratory. As additional proof of the lack of influence of the initial blood sugar content on the rate of glycolysis Table III is inserted to call attention to the glycolytic rate of the blood of a patient with diabetes mellitus both before and during management by diet and insulin.

The effect of insulin on the rate of glycolysis is also of interest. Three cases are presented (Table IV) to demonstrate the effect of insulin. In these cases, blood was withdrawn from the vein of one 
TABLE III

Glycolysis before and during diabetic management (Case D. F. B.)

\begin{tabular}{r|c|c|c|c}
\hline \hline \multirow{2}{*}{ Hours } & \multicolumn{2}{|c|}{ Before diabetic management } & \multicolumn{2}{c}{ During diabetic management } \\
\cline { 2 - 5 } & Blood sugar & Sugar glycolyzed & Blood sugar & Sugar glycolyzed \\
\hline & mgm. per $100 c c$. & mgm. per 100 cc. & mgm. per 100 cc. & mgm. per $100 c c$. \\
0 & 372 & 0 & 277 & 0 \\
2 & 341 & 31 & 239 & 38 \\
4 & 300 & 72 & 198 & 79 \\
6 & 265 & 107 & 140 & 137 \\
8 & 197 & 175 & 118 & 159 \\
10 & 120 & 252 & 73 & 204 \\
12 & 102 & 270 & 34 & 243 \\
14 & 67 & 305 & & \\
\hline
\end{tabular}

arm and, without removing the needle, insulin was injected directly into the vein. After three minutes blood was withdrawn from the vein of the other arm. Glycolysis was allowed to proceed in the usual way. It will be observed that the rates of glycolysis are parallel and that there is no indication of an increased glycolytic rate due to the direct action of insulin when it is added to the blood in this manner. These results are in accord with the work of Eadie, Macleod and Noble (23), who found no evidence of a modified glycolytic rate in the blood of dogs drawn before and after the subcutaneous administration of insulin. Raab (24), Bierry, Rathery and Kourilsky (25), Ducceschi (26), Hepburn and Latchford (27), and Lemann and Liles (8) noted no change in the amount of glycolysis after insulin. Mauriac and Aubertin (28) concluded that insulin acts without changing the glycolytic power of the tissues. The authors' results do not support the work of Achard (29), who maintained that insulin acts by decreasing hyperglycemia and increasing the rate of glycolysis, nor of Thalhimer and Perry (16), who stated that the amount of glycolysis varies directly with the administration of insulin.

Under standard conditions of technique there are marked variations in the rate of glycolysis, as is evident from a study of Table I. The plasma is the only blood element which is incapable of displaying any glycolytic activity; if incubated under sterile conditions for several days, its original sugar content remains unchanged. Plasma is not 


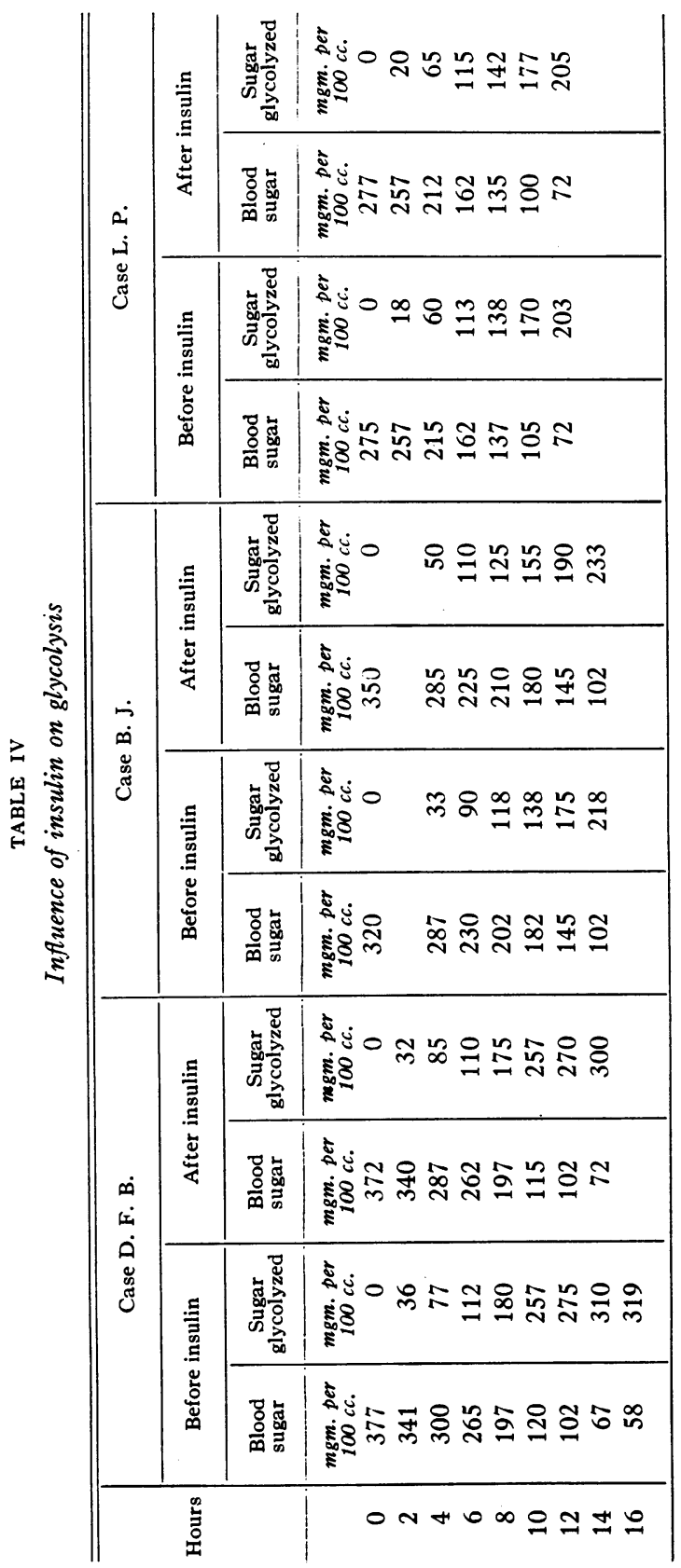


essential as a carrier of glucose for the cells; the author has shown that Tyrode's solution may be substituted for it without affecting the glycolytic rate, and Kawashima (30) has substituted physiological salt solution and Locke's solution with equal success. Rona and Doblin (31) and von Noorden (32) attributed some glycolytic power to blood serum, but it is conceded by Irving (12), Milne and Peters (33) and Macleod (22) that neither blood serum nor plasma is able to glycolyze any of the sugar which they contain.

The erythrocytes are the cause for the disappearance of much of the sugar in vitro. Bloods containing large numbers of erythrocytes glycolyze sugar more rapidly than bloods containing fewer red blood corpuscles, other things being equal. The results of a typical observation of the rate of glycolysis in a normal blood and in the same blood when the cellular elements are diluted with its own serum are presented in Table V. In Table VI the glycolytic rates of anemic bloods

TABLE V

Effect of diluting blood on glycolysis (Case H. B.)

\begin{tabular}{|c|c|c|c|c|c|c|}
\hline \multirow{2}{*}{ Hours } & \multicolumn{2}{|c|}{$\begin{array}{l}\text { Whole blood, } 46 \text { per cent } \\
\text { corpuscles, } 54 \text { per cent plasma }\end{array}$} & \multicolumn{2}{|c|}{$\begin{array}{l}\text { "Modified" blood, } 30 \text { per cent } \\
\text { corpuscles, } 70 \text { per cent plasma }\end{array}$} & \multicolumn{2}{|c|}{$\begin{array}{l}\text { "Modified" blood, } 23 \text { per cent } \\
\text { corpuscles, } 77 \text { per cent plasma }\end{array}$} \\
\hline & $\begin{array}{l}\text { Blood } \\
\text { sugar }\end{array}$ & $\underset{\text { glycolyzed }}{\text { Sugar }}$ & $\begin{array}{l}\text { Blood } \\
\text { sugar }\end{array}$ & $\underset{\text { glycolyzed }}{\text { Sugar }}$ & $\begin{array}{l}\text { Blood } \\
\text { sugar }\end{array}$ & $\underset{\text { glycolyzed }}{\text { Sugar }}$ \\
\hline 0 & $\begin{array}{c}\text { mgm. per } \\
100 \text { cc. } \\
155\end{array}$ & $\begin{array}{c}\text { mgm. per } \\
100 \text { cc. } \\
0\end{array}$ & $\begin{array}{c}\text { mgm. per } \\
100 \text { cc. } \\
159\end{array}$ & $\begin{array}{c}\text { mgm. per } \\
100 \text { cc. } \\
0\end{array}$ & $\begin{array}{c}\text { mgm. per } \\
100 \text { cc. } \\
186\end{array}$ & $\begin{array}{c}\text { mgm. per } \\
100 \text { cc. } \\
0\end{array}$ \\
\hline 2 & 122 & 33 & 130 & 29 & 162 & 24 \\
\hline 4 & 77 & 78 & 96 & 63 & 137 & 49 \\
\hline
\end{tabular}

TABLE VI

Effect of concentrating anemic blood on glycolysis (Case B. A.)

\begin{tabular}{|c|c|c|c|c|}
\hline \multirow{2}{*}{ Hours } & \multicolumn{2}{|c|}{$\begin{array}{c}\text { Whole blood, } 21 \text { per cent corpuscles, } \\
79 \text { per cent plasma }\end{array}$} & \multicolumn{2}{|c|}{$\begin{array}{c}\text { “Modified" blood, } 39 \text { per cent corpuscles, } \\
61 \text { per cent plasma }\end{array}$} \\
\hline & Blood sugar & Sugar glycolyzed & Blood sugar & Sugar glycolyzed \\
\hline 0 & $\begin{array}{c}\text { mgm. per } 100 \mathrm{cc} . \\
136\end{array}$ & $\begin{array}{c}m g m . \text { per } 100 c c . \\
0\end{array}$ & $\begin{array}{c}\text { mgm. per } 100 \mathrm{cc} . \\
132\end{array}$ & $\begin{array}{c}\text { mgm. per } 100 \mathrm{cc} . \\
0\end{array}$ \\
\hline 2 & 115 & 21 & 88 & 44 \\
\hline 4 & 94 & 42 & 51 & 81 \\
\hline
\end{tabular}


are compared with the rates observed in the same specimens after removal of enough serum to bring the cellular concentration approximately to normal. These experiments confirm Harrop's (34) demonstration that the erythrocytes have glycolytic power, and indicate that their concentration is important. These results are in accord with those reported by Kawashima (30) and by Doyon and Morel (35). Falcon-Lesses (3) and Cook and Somogyi (36) reached a similar conclusion after studies of the glycolytic rate in erythremia.

Not only is the concentration of erythrocytes a factor in glycolysis, but the nature of the red blood corpuscles is important. It has been demonstrated (37) that in diseases of the hematopoietic system characterized by great bone marrow activity and the releasing into the blood stream of great numbers of young and even immature red blood corpuscles there is a marked increase in the amount of sugar glycolyzed. In this connection it is interesting to note that Harrop (34), Morawitz (38) and Derra (39) have reported the increased use of oxygen by immature erythrocytes. No attempt was made in this study to correlate the rate of glycolysis and the oxygen consumption but, in view of the conclusions drawn by Glover, Daland and Schmitz (40) regarding the oxygen utilization and glycolytic rate of normal and leukemic leucocytes, such a study is desirable.

Of importance, also, in the study of glycolysis is the glycolytic power of the leukocytes. Although they exist in blood in relatively small numbers, they have a high glycolytic power, as may be demonstrated by the increased rate of disappearance of sugar accompanying slight leukocytosis. Table I shows the high glycolytic rate characteristic of leukemia. This observation has also been made by Glover, Daland and Schmitz (40), Falcon-Lesses (3), and Lepine and Boulud (41). However, as pointed out by Bürger (9), Falcon-Lesses (3) and Schmitz and Glover (4) in their observations of chronic myelogenous leukemia and lymphatic leukemia, the amount of sugar glycolyzed is not necessarily in proportion to the total number of leucocytes present. This suggests that the various types of leucocytes have different glycolytic abilities, and that it is the young leucocytes (particularly the cells of the myelocytic series) which possess the greatest glycolytic power. This is revealed very clearly in Table I and has been emphasized by all investigators studying glycolysis in leukemic bloods. Lymphocytes, 
on the other hand, possess a lower glycolytic activity, as is demonstrated by the fact that the blood in lymphatic leukemia utilizes much less sugar per unit of time, although the number of white blood cells may be as great as in myeloid leukemia. Mauriac (42), Bürger (9), Macleod (43) and the author have shown that polymorphonuclear leucocytes are endowed with a much greater glycolytic power than mononuclear leucocytes.

It may be postulated that the endothelial cells have glycolytic ability, but these cells occur in the blood in such small numbers that they can be of very little importance in the utilization of sugar. Blood platelets which Warburg (44) states have a measurable oxygen consumption can scarcely be much of a factor in glycolysis, especially if they are effectively removed with the fibrin during defibrination as Harrop (34) believes.

\section{SUMMARY AND CONCLUSIONS}

1. A study of the rate of glycolysis in bloods from 80 different patients with widely different diseases is presented.

2. There is no correlation of the age or sex of the patients and the rate of glycolysis.

3 . The glycolytic rate is markedly influenced by temperature. Glycolytic studies should be performed at $37^{\circ}$ C.- the optimum temperature for the disappearance of sugar from blood in vitro.

4. Citrates and oxalates, when used as anticoagulants, retard glycolysis in drawn blood in proportion to the amount in which they have been added.

Fluorides arrest glycolysis.

Defibrination or heparinization does not interfere with the rate of glycolysis, and blood so treated should be used for glycolytic studies.

5. The rate of glycolysis bears no relationship to the initial glucose content of the blood.

6. Glycolysis in vitro is not affected by insulin.

7. Both erythrocytes and leucocytes are responsible for the glycolytic power of blood, and their number, type, age, and physiological integrity are important factors.

8. Glycolysis is a complex process involving certain variables which must be controlled if the results are to be correct. 


\section{BIBLIOGRAPHY}

1. Bernard, C. Leçons de physiologie expérimentale appliquée à la médicine. Paris, Baillière, 1856.

2. Gibson, R. B., Mitchell, K. and Larimer, R. N., J. Iowa State Med. Soc., 1925, xv, 225. Management of Diabetes Mellitus with Maintenance Diets.

3. Falcon-Lesses, M., Arch. Int. Med., 1927, xxxix, 412. Glycolysis in Normal and Leukemic Blood.

4. Schmitz, H. L. and Glover, E. C., J. Biol. Chem., 1927, Ixxiv, 761. Glycolysis in Leucemic Blood.

5. Birchard, D. E., J. Lab. and Clin. Med., 1923, viii, 346. Loss of Sugar in Oxalated Blood.

6. White, H. L. and Watson, L., J. Lab. and Clin. Med., 1920, vi, 45. A Note on the Stability of Drawn Blood.

7. John, H. J., Ann. Clin. Med., 1925, iii, 667. Glycolysis.

8. Lemann, I. I. and Liles, R. T., J. Lab. and Clin. Med., 1926, xi, 339. Glycolysis at Varying Blood Sugar Levels.

9. Bürger, M., Ztschr. f. d. ges. exper. Med., 1923, xxxi, 1. Untersuchungen über Hämoglykolyse. I.

10. Major, R. H., J. Am. Med. Assoc., 1923, lxxxi, 1952. Potassium Fluorid as a Preservative for Blood.

11. Dickens, F. and Simer, F., Biochem. J., 1929, xxiii, 936. Observations on Tissue Glycolysis: The Effect of Fluoride and Some Other Substances.

12. Irving, J. T., Biochem. J., 1926, xx, 613. The Degradation of Glucose by the Blood Corpuscle of the Rabbit.

13. Denis, W. and Giles, U., J. Biol. Chem., 1923, lvi, 739. On Glycolysis in Diabetic and Non-Diabetic Blood.

14. Mauriac, P., Compt. rend. Soc. de biol., 1921, lxxxiv, 311. Technique pour Mesurer le Pouvoir Glycolytique du Sang.

15. Stammers, A. D., Physiol. Rev., 1926, vi, 630. A Review of Recent Advances in the Study of Blood Sugar and Diabetes.

16. Thalhimer, W. and Perry, M. C., J. Am. Med. Assoc., 1923, lxxx, 1614. Diminished Glycolysis in the Blood in Diabetes.

17. Cajori, F. A. and Crouter, C. Y., J. Biol. Chem., 1924, 1x, 765. A Comparison of the Rate of Glycolysis in Different Bloods with Special Reference to Diabetic Blood.

18. Katayama, I., J. Lab. and Clin. Med., 1926, xii, 239. Studies in Blood Glycolysis.

19. Negelein, E., Biochem. Ztschr., 1925, clviii, 121. Versuche über Glykolyse.

20. Mackenzie, G. M., J. Exp Med., 1915, xxii, 757. An Experimental Study of Blood Glycolysis. The Effects of Thyroid and Adrenal Extracts and Phlorhizin on Glycolysis in Vitro. 
21. Tolstoi, E., J. Biol. Chem., 1924, Ix, 69. Glycolysis in Bloods of Normal Subjects and of Diabetic Patients.

22. Macleod, J. J. R., J. Biol. Chem., 1913, xv, 497. Blood Glycolysis: Its Extent and Significance in Carbohydrate Metabolism.

23. Eadie, G. S., Macleod, J. J. R. and Noble, E. C., Am. J. Physiol., 1923, lxv, 462. Insulin and Glycolysis.

24. Raab, W., Biochem. Ztschr., 1928, cxciv, 473. Beitrag zum Glykolyseproblem.

25. Bierry, H., Rathery, F. and Kourilsky, R., Compt. rend. Soc. de. biol., 1925, xcii, 480. Le Pouvoir Glycolytique est-il Diminué dans le Sang des Diabétiques.

26. Ducceschi, V., Boll. d. Soc. med. chir. di Pavia, 1924, xxxvi, 215. Insulina e glicolisi.

27. Hepburn, J. and Latchford, J. K., Am. J. Physiol., 1922, 1xii, 177. Effect of Insulin (Pancreatic Extract) on the Sugar Consumption of the Isolated Surviving Rabbit Heart.

28. Mauriac, P. and Aubertin, E., Compt. rend. Soc. de biol., 1924, xci, 554. Etude de la Glycolyse in vivo par le dosage du sucre sanguin-artériel et veineux de certains organes, avant et après injection d'insuline.

29. Achard, M. C., Bull. Acad. de med., 1924, xcii, 880 . Remarques sur le diabète l'insuffisance glycolytique et l'insuline.

30. Kawashima, Y., J. Biochem., 1924, iv, 411. Über die Glykolytische kraft des Blutes. III.

31. Rona, P. and Döblin, A., Biochem. Ztschr., 1911, xxxii, 489. Beiträge zur Frage der Glykolyse. II.

32. von Noorden, K., Biochem. Ztschr., 1912, xlv, 94. Über Milchsäurebildung im Blute.

33. Milne, L. S. and Peters, H. L. B., J. Med. Res., 1912, xxi, 415. Observations of the Glycolytic Power of the Blood and Tissues in Normal and Diabetic Conditions.

34. Harrop, G. A., Arch. Int. Med., 1919, xxiii, 745. Oxygen Consumption of Human Erythrocytes.

35. Doyon, M. and Morel, A., Compt. rend. Soc. de biol., 1903, lv, 215. Rôle des éléments figurés du sang dans la glycolyse.

36. Cook, J. E. and Somogyi, M., Arch. Int. Med., 1929, xliv, 813. The Rate of Glycolysis in Erythremia.

37. Barer, A. P., Needles, R. J. and Baldridge, C. W., Proc. Soc. Exp. Biol. and Med., 1929, xxvii, 176. A Study of the Metabolism of Reticulocytes.

38. Morawitz, P., Arch. f. exper. Path. u. Pharmakol., 1909, 1x, 298. Über Oxydationsprozesse im Blut.

39. Derra, E., München. med. Wchnschr., 1928, 1xxv, 1494. Sauerstoffzehrung und Vitalgranulation bei perniziöser Anämia nach Leberdiät. 
40. Glover, E. C., Daland, G. A. and Schmitz, H. L., Arch. Int. Med., 1930, xlvi, 46. The Metabolism of Normal and Leukemic Leukocytes.

41. Lépine, R. and Boulud, R., Biochem. Ztschr., 1911, xxxii, 287. Über den Zucker des Plasmas und der Blutkörperchen.

42. Mauriac, P., Compt. rend. Soc. de biol., 1929, ci, 374. Etude du Pouvoir Glycolytique des Polynucléaires.

43. Macleod, J. J. R., Physiol. Rev., 1921, i, 208. The Sugar of the Blood.

44. Warburg, O., Ztschr. f. Physiol. Chem., 1909, lix, 112. Zur Biologie der roten Blutzellen. 